\author{
удк 008:004.9
}

\title{
- GARTNER HYPE CYCLE ЯК МЕТОДИКА АНАЛІЗУ ЗАКОНОМІРНОСТЕЙ РОЗВИТКУ ІНФОРМАЦІЙНО- КОМУНІКАЦІЙНИХ ТЕХНОЛОГІЙ
}

\section{Трач Юлія Василівна \\ Кандидат педагогічних наук, профресор, \\ ORCID: 0000-0003-2963-0500, e-mail:0411@ukr.net, \\ Київський національний університет культури і мистецтв, \\ вул. Є. Коновальця, 36, Київ, Україна, 01133}

\section{- Для цитування:}

Tрач, Ю.В. (2021). Gartner Hype Cусlе як методика аналізу закономірностей розвитку інформаційно-комунікаційних технологій. Питання культурології, (37), 210-221. doi: https://doi.org/10.31866/2410-1311.37.2021.236024.

\section{- Анотація}

Мета статті - схарактеризувати Gartner Hype Cycle methodology як спробу виявлення закономірностей розвитку сучасних інформаційно-комунікаційних технологій. Методологія дослідження ґрунтується на застосуванні загальнонаукової групи формально-логічних методів, таких як аналіз, синтез, абстрагування, а також системного і структурно-функціонального підходів. Наукова новизна полягає у тому, що у роботі розширено уявлення про методики аналізу тенденцій і закономірностей розвитку сучасних інфрормаційно-комунікаційних технологій, звернено увагу на необхідність врахування даних наявних методик оцінювання стану розвитку ІКТ в гуманітарних дослідженнях для отримання більш обґрунтованих висновків. У статті акцентовано на необхідності всебічного і ґрунтовного аналізу з погляду гуманітаристики досягнень, тенденцій, закономірностей і перспектив розвитку інформаційнокомунікаційних технологій - одного з ключових чинників життєдіяльності сучасного суспільства. Подано класифікацію ІКТ, що ґрунтується на врахуванні видів і способів отримання та обробки інформації. Наведено детальний аналіз Gartner Hype Cycle methodology, звернено увагу на її недоліки. Висновки. Наголошено, що оскільки сфера інформаційних і комунікаційних технологій схильна до постійних змін і надзвичайно швидкого, а головне - непередбачуваного розвитку мало не щохвилини, то кожна зміна поколінь засобів інформаційної технології вимагає не просто навчання і підвищення кваліфікації, а й радикальної зміни мислення фахівців і користувачів, зміни обладнання тощо. Звернено увагу, що розробка та використання в численних сферах життєдіяльності людини NBIC-технологій зумовлює необхідність, по-перше, прийняття неминучості процесу застосування прогресивних технологій, якими б неймовірними і фантастичними не здавалися наслідки їх впровадження; по-друге, послідовного 
культурологічного осмислення й адекватного супроводу пов'язаних із цим процесом досягнень і ризиків.

Ключові слова: методика Gartner Нуре Cycle; інформаційно-комунікаційні технології; закономірності розвитку інформаційно-комунікаційних технологій

\section{- Вступ}

Вектор соціокультурної динаміки сьогодні істотною мірою визначається інноваційними процесами, що відбуваються під впливом науково-технічного прогресу у сорері соціально-економічних і навіть духовних технологій. Ці процеси взаємопов'язані з процедурами відкриттів, які в принципі $є$ важко прогнозованими, і тому невизначеність постає нормою розвитку сучасного інноваційного суспільства. Саме через те, що потужність сучасних технологій стає все більш непередбачуваною, в науці переважає думка, що XXI ст. має стати століттям гуманітарного знання, за допомогою якого людина змогла б приборкати ті сили, які нею ж і були активовані в попередні часи. Отож, об'єктивні тенденції суспільного розвитку та виникаючі проблеми змушують по-новому поглянути на роль гуманітарного знання і відповідно до цього вибудовувати всю систему не лише гуманітарних досліджень, а й гуманітарної освіти. Відтак, одним із питань, що потребує всебічного і ґрунтовного аналізу й переосмислення з точки зору гуманітаристики, є досягнення, тенденції, закономірності і перспективи розвитку інформаційних технологій (IT) 一 одного із ключових чинників життєдіяльності сучасного суспільства. Дослідження у цьому напрямі вкрай важливі, оскільки без гуманітарного знання і вироблених на його основі критеріїв потужні індустріальні, інформаційні інструменти, створені людським генієм, можуть перетворитися на засіб поневолення самої людини. Саме тому сьогодні необхідний ґрунтовний гуманітарний аудит, який би допомагав суспільству спрямовувати енергію інноваційного процесу в творчому напрямі.

Використання дослідницьких звітів авторитетних міжнародних організацій з виявлення тенденцій і закономірностей появи і подальшого розвитку IT властиве переважно IT-експертам і практикам в IT-сфері, і майже не зустрічається в наукових працях, в яких заведено аналізувати перспективи розвитку IT, ґрунтуючись на прогнозах футурологів, висновках представників гуманітаристики, які недостатньо обізнані із специфікою розвитку IT-сфери тощо. Це призвело до появи однотипних публікацій, в яких спрощено висвітлюється означене питання. Можна відзначити лише окремі праці українських і закордонних дослідників, які торкаються проблематики структури та складників IT-ринку, індексу мережевої готовності на основі розроблення трендів субіндексу «використання IT», у тому числі й методик аналізу тенденцій і закономірностей появи і подальшого розвитку IT. Так, С. Войтко та Т. Сакалош (2007) досліджують IT-ринок і на основі цих даних пропонують структуру ринку інформаційно-комунікаційних товарів та послуг. Тенденції розвитку ІТ-ринку також досліджує О. Бавико (2015), і пропонує власну модель його структури, що включає систему взаємопов'язаних сегментів із продажу апаратного забезпечення та надання відповідних послуг у межах галузей інформаційних технологій і телекомунікації. О. Чорна (2012) обґрунтовує 
можливість використання циклу надочікувань для виявлення тенденцій розвитку хмарних технологій. У працях А. Ставицької (2016; 2017) розглянуто потенціал і тенденції розвитку IT-ринку України, а також інтегральні характеристики світового IT-ринку, здійснено аналіз індексних показників, які найбільше використовуються для з'ясування глобальної конкурентоздатності країн на світовому IT-ринку тощо. С. Шевченко (2017) у своїй праці робить наголос на специфічних ознаках людиноорієнтованих технологій у контексті NBICS-конвергенції, при цьому звертає увагу і на цикл хайпа. $Є$. Конніков та О. Коннікова (Конников \& Конникова, 2020) на підставі аналізу наукових здобутків з таких напрямів, як Science, Technology and Innovation Studies i Media Studies, узагальнюють основні дослідницькі питання в галузі вивчення хайпа, а також обґрунтовують його характерні ознаки в digital-середовищі, і врешті решт дають відповідь на питання, яким чином можна використовувати теорію життєвого циклу для монетизації хайпа, оперативно реагуючи на стрімке зростання популярності в digital-cepeдовищі певної події чи явища. Таким чином, дослідження останніх років не повною мірою використовують експертні висновки щодо тенденцій і закономірностей появи і розвитку IT, що робить наявні теоретичні напрацювання з цього питання недостатньо обґрунтованими, особливо в гуманітарних дослідженнях.

\section{- Мета статті}

Мета статті - схарактеризувати Нуре Cусlе як спробу виявлення закономірностей розвитку інформаційно-комунікаційних технологій. Методологія дослідження ґрунтується на застосуванні загальнонаукової групи формально-логічних методів, таких як аналіз, синтез, абстрагування, а також системного і структурно-функціонального підходів.

\section{- Виклад матеріалу дослідження}

Сьогодні рівень розвитку інформаційних технологій досяг небувалого рівня і здатен задовольнити професійні й побутові потреби людини мало не в усіх сферах її життєдіяльності. Однак класифікувати усю сукупність IT за чітко визначеними ознаками вкрай складно, зважаючи на кілька аргументів: а) IT володіють інструментарієм: технічним, інформаційним, програмним, методичним та організаційним забезпеченням; б) ІТ постійно розвиваються, при цьому з'являються нові технології, що ґрунтуються на попередніх розробках, а існуючі IT розвиваються і видозмінюються на основі нових методів, процесів, інструментальних і технічних засобів реалізації IT. Відтак розробити класифікацію IT з використанням традиційно застосовуваного ієрархічного представлення класифікацій практично неможливо.

Однією з найбільш докладних є класифікація IT, що ґрунтується на врахуванні видів і способів отримання та обробки інформації, виходячи з положення про мету IT - реєстрація, зберігання, перетворення і надання інформації для аналізу і використання ії̈ людиною при прийнятті рішень. Згідно з цією класифікацією, головними видами IT є: 1) технології спілкування людини та EOM (операційні системи; технології алгоритмізації і програмування; технології шифрування і кодування; технології тестування); 2) технології реєстрації, 
зберігання і представлення даних (технології створення баз даних, СУБД; технології побудови і створення сховищ даних; хмарні технології; технології мультимедіа); 3) технології пошуку інформації (технології пошуку в базах даних; технології документального інформаційного пошуку; технології пошуку фрактографрічних даних); 4) технології обробки і транзакцій (технології обробки числових і символьних даних; технології підготовки текстових і табличних даних; OLPT-технології); 5) технології обробки даних та отримання знань для прийняття рішень (OLPT-технології і «вітрини»; технології отримання знань з даних Data Sience (KDD, ETL, Data Mining); методологія SADT, RAD- і CASE-технології; технології імітаційного моделювання); 6) технології створення систем управління підприємством та організаціями (технології створення автоматизованих систем управління та автоматизованих інформаційних систем; технології створення предметно-орієнтованих інформаційних систем; технології проєктування та налаштування документальних і фрактографічних інформаційнопошукових систем; технології створення автоматизованих систем нормативнометодичного забезпечення управління підприємства як автоматизованих документально-фрактографрічних інформаційно-пошукових систем; технології проєктування і вибору корпоративних інформаційних систем); 7) емерджентні технології (інтернет-технології; інтелектуальні технології; нано-, біо, інформаційні, конвергентні технології - NBIC-технології) (Волкова и др., 2015).

Усі ці технології не лише покликані допомогти людству у розв'язанні численних проблем, зокрема в пом'якшенні наслідків глобальних криз, наданні додаткових можливостей у вирішенні енергетичних, екологічних, демографічних та цілого ряду інших проблем, а й повинні бути орієнтовані на досягнення суспільного блага, соціальної гармонії. Саме тому розвиток такої кількості різноманітних за призначенням IT, розпочатий із моменту появи першого персонального комп'ютера, багато в чому безпосередньо залежить від рівня виникаючих потреб в IT. Цей процес відбувається за певними законами, в якості яких міжнародна організація Gartner - одна з найбільш авторитетних дослідницьких та консалтингових компаній, що спеціалізується на IT-ринку, пропонує так званий цикл хайпа (Hype Cycle) - це крива зрілості технології, що графічно представляє стадії становлення технологічного нововведення (Gartner, n.d.). Саме поняття «хайп» (від англ. - Нуре), що використовується для опису певного явища («хайповий»), точно визначити складно, - швидше це синонім слів «ажіотаж», «галас», що позначають сплеск інтересу, захоплення чимось, отож кожну «хайпову» подію чи явище можна описати певною тривалістю періодів наростання і спаду інтересу. Цей френомен спостерігається і при появі будь-якої нової техніки - чи то поява планшетів на ринку, чи впровадження нової CRM-системи на підприємстві. Згідно із циклом хайпа (в Україні, щоправда, більш поширеною назвою методики є «цикл надочікувань» ("Цикл надочікувань", 2019)), більшість нових технологій проходить у процесі свого розвитку п'ять етапів, проте деякі технології розвиваються надто швидко і «пропускають» деякі етапи, інші ж, навпаки, періодично повертаються на початок. Серед цих фаз:

- технологічний тригер (англ. technology trigger) - поява інновації, перші публікації про нову технологію; 
- пік надмірних очікувань (Peak of Inflated Expectation) - від нової технології очікують революційних змін; технологія, завдяки новизні, стає популярною і предметом широкого обговорення в суспільстві;

- звільнення від ілюзій (Trough of Disillusionment) - виявляються недоліки технології, а втрата новизни не сприяє появі захоплених публікацій, у суспільстві відзначається розчарування новою технологією;

- подолання недоліків (Slope of Enlightenment) - усуваються основні недоліки, інтерес до технології повільно повертається, технологія починає впроваджуватися в комерційних проєктах;

- плато продуктивності (Plateau of Productivity) - настання зрілості технології; суспільство сприймає технологію як даність, усвідомлюючи ії переваги та обмеження (Gartner, n.d.).

Тривалий час ці стадії і їх послідовність не ставилися під сумнів. Однак з ускладненням й урізноманітненням IT очевидною стала недосконалість Нуре Cycle, хоча фрази зрілості технології й досі вважаються незаперечними. Так, докладний аналіз циклів Gartner протягом 20 років про прийняття суспільством нової технології, здійснений віцепрезидентом інвестиційного фронду Icon Ventures Майклом Маллані (Mullany, 2016), засвідчив і помилковість прогнозів Gartner стосовно конкретних технологій, і неврахування в Нуре Сусlе багатьох основних технологій. Насправді на переконання М. Маллані, технології не підкоряються кривій зрілості. Одні технології через деякий час після своєї появи стали фооновим шумом - наприклад, об'єктно-орієнтоване програмування, другим, які вважалися практично готовими, знадобилися десятиліття, щоб досягти зрілості - до них відноситься технологія розпізнавання мови, треті взагалі зникли. На кривій Gartner Hype Сусlе з'явилося більш як двісті унікальних технологій, але лише кілька з них пройшли весь шлях від початку до кінця: це хмарні обчислення, 3D-друк, пошук природною мовою та електронне чорнило (Mullany, 2016). 3-поміж цих технологій понад п'ятдесят з'явилися на кривій зрілості тільки один раз: наприклад, HTML5 (відкрита платформа, призначена для створення вебдодатків, і яка використовує аудіо, відео, графіку, анімацію та ін.). 20 \% усіх технологій, які відстежувалися протягом кількох років в Нуре Сусlе, стали застарілими ще до того, як досягли успіху, наприклад, корпоративні RSS - фрормат читання новин, після появи якого вважалося, що він може стати головним корпоративним форматом для поширення інформації. У 2006 році цю технологію назвали перспективною і зростаючою, але вже в 2007 році вона «провалилася». Інший приклад - коміркова топологія (Mesh networks) - мережева архітектура маршрутизованих мереж, в яких будь-який комп'ютер міг стати комутатором для інших пристроїв. Ця технологія на кривій Gartner Hype Cусlе з'являлася дев'ять разів за одинадцять років як технологія, що перебуває на фазі «подолання недоліків», проте виявилася занадто складною для організації роботи і так і залишилася вузькоспеціалізованою (Mullany, 2016).

Ще однією характеристикою розвитку технологій $€$ те, що вони можуть залишитися нереалізованими, попри усю свою перспективність. Наприклад, у 2002 році на Hype Cycle з'явилася Microsoft Passport - система єдиного входу, коли користувач може використовувати єдині ідентифрікаційні дані на різних ресур- 
cax. Але технологія була не готова до масового ринку і розроблялася на застарілих стандартах. Незважаючи на це ідея Microsoft була далекосяжною, тому уже через п'ять років завдяки спільним зусиллям компаній Google, Twitter i Magnolia з'явився Oauth - сервіс, який дає змогу авторизуватися через популярні соцмережі на більшості сайтів з логіном, і таким чином за рахунок великої користувальницької бази набув поширення (Mullany, 2016).

За висновками М. Маллані, є ряд основних технологій, які, з огляду на гучні невдачі, постійно «перероджуються» в Нуре Суcle, іноді одразу під кількома назвами. Кожне таке «переродження» робить крок уперед у розвитку технології, залишаючи базу для наступників, тобто попри те, що вони не стають масовими, вони неодноразово продукують нові стартапи з істотним ривком у розвитку. М. Маллані називає їх «технологічними марафонами». Це, зокрема, технологія розпізнавання мови, яка вперше з'явилася на кривій зрілості технологій у 1995 році одразу на «плато продуктивності». Технології перетворення тексту в мовлення і миттєвого перекладу з однієї мови на іншу, насправді далекі від якісної реалізації, з'являлися у 2002, 2005, 2006 роках, але тільки через два десятиліття вдалося розробити якісне програмне забезпечення завдяки технологіям машинного навчання. Інший приклад - децентралізована мережа, яка вперше з'являлася на кривих зрілості у 2002 році, а потім перетворилася на блокчейн і криптовалюту. Тобто, нереалізовані свого часу технології можуть стати джерелом ідей для інженерів, наприклад, у 1990-х роках на кривій зрілості з'явилися технології аналізу великих даних і контент-аналізу — «інтелектуальна обробка даних». У 2000-х їх замінила аналітика, а у 2010-му — великі дані (big data). Цей процес закономірний, адже кожні десять років з'являється нове покоління технологій, які обробляють все більше даних, обсяг яких збільшується (Mullany, 2016).

M. Маллані (Mullany, 2016) у своєму дослідженні згадує також й технології, які повторюються з року в рік, але, на його переконання, можуть так і не бути реалізованими. «Занадто футуристичними» М. Маллані вважає ідеї розробки квантового комп'ютера та нейронного інтерфейсу. I дійсно, попри помітний прогрес, ці технології досі не реалізовані, хоча про розробку квантового комп'ютеpa Sycamore компанією Google повідомлялося у вересні 2019 року (Рінкон, 2019). У статті, розміщеній на сайті NASA, йшлося про те, що процесор нового комп'ютера нібито виконав за 3 хвилини і 20 секунд розрахунки, на які найпотужнішому сьогодні комп'ютеру Summit знадобилося б 10 тис. років. Однак прототип квантового комп'ютера так і не був представлений громадськості, а стаття невдовзі була видалена. Можливість квантових обчислень досі порівнюють із випробуваннями першої атомної бомби чи польотом у космос першого супутника.

Що ж стосується нейронного, або нейрокомп'ютерного інтерфейсу - це пристрій, що забезпечує зв'язок між нервовими імпульсами мозку і комп'ютерною системою, даючи змогу користувачеві взаємодіяти з цією системою за допомогою думки. Нейронний інтерфейс з'єднує людський мозок з електронними пристроями і потрібен для використання у системах віртуальної і доповненої реальності як заміна решті спорядження типу навушників або візуального каналу, для використання об'єктів доповненої реальності, в «розумному домі» і на- 
віть в медицині. Однак, як і з квантовим комп'ютером, незважаючи на помітний прогрес у сфері управління комп'ютерами за допомогою мозкової активності, розробок нейронного інтерфейсу все ще недостатньо для повної та ефективної реалізації.

Ще однією тенденцією розвитку IT $є$ те, що чимало технологій можуть залишитися непоміченими навіть у професійному середовищі, проте згодом вони стають основою багатьох додатків і платфрорм. Наприклад, апаратна віртуалізація х86 - найважливіша технологія центрів обробки даних останнього десятиліття, вперше впроваджена VMware; бази даних NoSQL — на початку 2000-х років стали основою баз даних, не заснованих на SQL (MongoDB, Cassandra, Redis, Couch); Open Source - відкритий вихідний код, поширення якого як моделі ліцензування призвело до розвитку комп'ютерної інфраструктури, об'єднання людей в спільноти, а також до впровадження хмарних моделей.

Таким чином, підсумовуючи, М. Маллані (Mullany, 2016) звертає увагу на те, робити прогнози стосовно IT доволі складно, оскільки технології можуть або зникнути, або стати основою для інших технологій. При цьому працювати над одними технічними проблемами доводиться протягом десятиліть, а інші технології роблять прогрес, на який ніхто не очікує. Появу одних технологій можна порівняти зі спалахами, а інші зникають нереалізованими. У цьому непередбачуваному процесі появи технологій та їх реалізації однозначним і незмінним має залишитися пошук можливості їх застосування на благо людства, на благо соціотехнічному динамізму.

Gartner Hype Cycle - не єдина методика, що тривалий час застосовується аналітичними центрами для вивчення тенденцій і закономірностей появи і подальшого розвитку IT. Йдеться про такі методики, як: Магічний квадрант (Gartner Magic Quadrant), Годинник IT-ринку (Gartner IT Market Clock), Аналіз частки ринку (Market Share Analysis), Прогнозування ринку (Gartner Marker Forecast), кожна з яких має свої переваги. Наприклад, Magic Quadrant (Tadviser, 2019) - це графічне відображення ситуації на ринку, що дає змогу оцінити можливості продуктів і самих виробників. У своїх звітах Gartner розглядає не лише якість і можливості програмного забезпечення, а й характеристики розробника, наприклад досвід продажів і роботи з клієнтами, повноту розуміння ринку, бізнес-модель, інновації, стратегії маркетингу, продажів, розвитку індустрії та ін. На основі оцінювання за ключовими параметрами вендори поділяються на 4 групи: лідери, претенденти на лідерство, далекоглядні і нішеві гравці. Попри певну недосконалість та окремі звинувачення в упередженості дослідницьких звітів, які ґрунтуються на застосуванні зазначених методик, кожна з них має на меті надати фахівцям теоретичні і прикладні орієнтири в їх дослідженнях і практичній діяльності. Використання цих даних у гуманітарних дослідженнях, безперечно, сприятиме всебічному і глибшому розумінню тенденції розвитку IT, і на цій підставі виробленню більш обґрунтованих висновків.

\section{- Висновки}

Отже, сфера інформаційних і комунікаційних технологій схильна до постійних змін і надзвичайно швидкого, а головне — непередбачуваного розвитку мало 
не щохвилини. Лідери галузі постійно створюють нові технології, які впливають на розвиток всього людства на роки вперед. Тому кожна зміна поколінь засобів інформаційної технології вимагає не просто навчання і підвищення кваліфікації, а радикальної зміни мислення фрахівців і користувачів, зміни обладнання тощо. Усвідомлення того фракту, що розвиток сучасних IT не обмежується створенням нових гаджетів чи комп'ютерних програм, а підґрунтям проєктування і реалізації нових процесуальних форм загального соціокультурного синтезу - основи нового суспільства - стають NBIC-технології, зумовлює необхідність прийняття неминучості процесу впровадження прогресивних технологій, якими б дивними, неймовірними й навіть франтастичними не здавалися наслідки їх впровадження. Гуманітаристика, і культурологія у тому числі постає перед викликом не усуватися від пов'язаних із цим процесом досягнень і ризиків, а своєчасно і послідовно займатися їх осмисленням і адекватним супроводом.

Подальшого дослідження вимагають численні питання функціонування інформаційно-комунікаційних технологій у сучасному світі з точки зору культурології, зокрема у контексті цієї статті - аналіз динаміки поширення IT, аналіз антагонізму та єдності нових і традиційних видів IT тощо.

\section{- Список використаних джерел}

Бавико, О. (2015). Структура і тенденції розвитку ринку інформаційно-комунікаційних технологій. Торгівля і ринок України, 38, 141-151.

Войтко, С. В., \& Сакалош, Т. В. (2007). Ринок інформаційно-комунікаційних технологій: структура та аналіз. Вісник Національного університету "Львівська політехніка", 594, 384-392.

Волкова, В. Н., Васильев, А. Ю., Ефремов, А. А., \& Юрьев, В. Н. (2015). Классификация инфрормационных технологий. Открытое образование. https://cyberleninka.ru/ article/n/klassifikatsiya-informatsionnyh-tehnologiy-2

Конников, Е. А., \& Конникова, О. А. (2020). Исследование жизненного цикла "хайпа" в диджитал среде и возможностей его монетизации. Вестник Алтайской академии экономики и права, 11, 50-59.

Рінкон, П. (2019, 24 жовтня). Google: "квантовий комп'ютер" перевершив звичайні. ВВC.News.Україна. https://www.bbc.com/ukrainian/features-50165223

Ставицька, А. В. (2016). Потенціал ринку інформаційних технологій України: реалії та перспективи. Причорноморські економічні студії, 12(1), 39-43.

Ставицька, А. В. (2017). Оцінка позиціонування країн на світовому ринку інфоормаційних технологій: статистичні виміри індексного аналізу. Науковий вісник Ужгородського національного університету. Серія: Міжнародні економічні відносини та світове господарство, 12(2), 126-130.

Цикл надочікувань. (2019, 12 травня). В Вікіпедіï. http://surl.li/ngqt

Чорна, О.В.(2012). Використання циклу надочікувань для виявлення тенденцій розвитку хмарних технологій. В Хмарні технології в освіті, Матеріали Всеукраїнського науково-методичного Інтернет-семінару (с. 3-6), Україна, Кривий Ріг, Київ, Черкаси, Харків, 21 грудня 2012 р. Видавничий відділ КМІ.

Шевченко, С. Ю. (2017). ЦИкл "хайп" и человекоориентированные технологии. В П. Д. Тищенко (Ред.), Конвергенция технологий и дивергенция будущего 
человека. Рабочие тетради по биоэтике (с. 142-152). Издательство Московского гуманитарного университета.

Gartner. (n.d.). Gartner Hype Cycle. https://www.gartner.com/en/research/methodologies/ gartner-hype-cycle

Mullany, M. (2016, December 7). 8 Lessons from 20 Years of Hype Cycles. Linkedin. https:// www.linkedin.com/pulse/8-lessons-from-20-years-hype-cycles-michael-mullany

Tadviser. (2019, 1 фревраля). Магчческий квадрант Gartner Magic Quadrant (MQ). http:// surl.li/ngqf

\section{- References}

Bavyko, O. (2015). Struktura i tendentsii rozvytku rynku informatsiino-komunikatsiinykh tekhnolohii [The structure and tendencies of development of the market of information and communication technologies]. Trade and market of Ukraine, 38, 141-151 [in Ukrainian].

Chorna, O. V. (2012). Vykorystannia tsyklu nadochikuvan dlia vyiavlennia tendentsii rozvytku khmarnykh tekhnolohii [Using the cycle of expectations to identify trends in the development of cloud technologies]. In Khmarni tekhnolohii vosviti [Cloud technologies in education], Proceedings of the All-Ukrainian scientific-methodical Internet-seminar (pp. 3-6), Ukraina, Kryvyi Rih, Kyiv, Cherkasy, Kharkiv, December 21, 2012. Vydavnychyi viddil KMI [in Ukrainian].

Gartner. (n.d.). Gartner Hype Cycle. https://www.gartner.com/en/research/methodologies/ gartner-hype-cycle [in English].

Konnikov, E. A., \& Konnikova, O.A. (2020). Issledovanie zhiznennogo tsikla "khaypa" $v$ didzhital srede i vozmozhnostey ego monetizatsii [Research of the "hype" life cycle in the digital environment and the possibilities of its monetisation]. Bulletin of the Altai Academy of Economics and Law, 11, 50-59 [in Russian].

Mullany, M. (2016, December 7). 8 Lessons from 20 Years of Hype Cycles. Linkedin. https:// www.linkedin.com/pulse/8-lessons-from-20-years-hype-cycles-michael-mullany [in English].

Rinkon, P. (2019, Oktober 24). Google: "kvantovyi komp'iuter" perevershyv zvychaini [Google: "Quantum Computer" is superior to conventional ones]. BBC.News. Ukrainian. https:// www.bbc.com/ukrainian/features-50165223 [in Ukrainian]

Shevchenko, S. Yu. (2017). Tsikl "khayp" i chelovekoorientirovannye tekhnologii [Cycle of "hype" and human-oriented technologies]. In P. D. Tishchenko (Ed.), Konvergentsiya tekhnologiy i divergentsiya budushchego cheloveka. Rabochie tetradi po bioetike [Divergence of human future: the convergence of technologies their philosophical understanding and the ethical-legal regulation. Workbooks on Bioethics] (pp. 142152). Publishing house of the Moscow University for the Humanities [in Russian].

Stavytska, A. V. (2016). Potentsial rynku informatsiinykh tekhnolohii Ukrainy: realii ta perspektyvy [Potential of the information technology market of Ukraine: realities and prospects]. Black Sea Economic Studies, 12 (1), 39-43 [in Ukrainian]

Stavytska, A. V. (2017). Otsinka pozytsionuvannia krain na svitovomu rynku informatsiinykh tekhnolohii: statystychni vymiry indeksnoho analizu [Estimation of the positioning of countries on the world market of information technologies: statistical measurements of index analysis]. Scientific herald of the Uzhhorod national university. Series: 
International Economic Relations and the World Economy, 12(2), 126-130 [in Ukrainian].

Tadviser. (2019, February 1). Magicheskiy kvadrant Gartner Magic Quadrant (MQ) [Magic Quadrant Gartner Magic Quadrant (MQ)]. http://surl.li/ngqf [in English].

Tsykl nadochikuvan [The cycle of waiting]. (2019, May 12). In Wikipedia. http://surl.li/ngqt [in Ukrainian].

Voitko, S. V., \& Sakalosh, T. V. (2007). Rynok informatsiino-komunikatsiinykh tekhnolohii: struktura ta analiz [Market of information and communication technologies: structure and analysis]. Bulletin of the National University "Lviv Polytechnic", 594, 384-392 [in Ukrainian].

Volkova, V. N., Vasil'ev, A. Yu., Efremov, A. A., \& Yur'ev, V. N. (2015). Klassifikatsiya informatsionnykh tekhnologiy [Classification of information technologies]. Otkrytoe obrazovanie. https://cyberleninka.ru/article/n/klassifikatsiya-informatsionnyhtehnologiy-2 [in Russian].

\title{
- GARTNER HYPE CYCLE AS A METHODOLOGY FOR ANALYSING THE PATTERNS OF DEVELOPMENT OF INFORMATION AND COMMUNICATION TECHNOLOGIES
}

\author{
- Yuliia Trach \\ - PhD in Education, Professor, \\ ORCID: 0000-0003-2963-0500, e-mail:0411@ukr.net, \\ Kyiv National University of Culture and Arts, \\ Kyiv, Ukraine
}

\section{- Abstract}

The purpose of the article is to characterise the Gartner Hype Cycle methodology as an attempt to identify patterns of development of modern information and communication technologies. The research methodology is based on the application of a general scientific group of formal-logical methods, such as analysis, synthesis, abstraction, and systemic and structural-functional approaches. The scientific novelty is that the paper expands the idea of methods of analysis of trends and patterns of development of modern information and communication technologies, draws attention to the need to take into account existing methods of assessing the development of ICT in humanities to obtain more sound conclusions. The article emphasises the need for a comprehensive and thorough analysis within humanities achievements, trends, patterns, and prospects for developing information and communication technologies - one of the key factors in modern society. The classification of ICT is given, which is based on taking into account the types and methods of obtaining and processing information. A detailed analysis of the Gartner Hype Cycle methodology is provided; attention is paid to its shortcomings. Conclusions. It is emphasised that since the field of information and communication technologies is subject to constant changes and extremely fast, and most importantly - unpredictable development almost every minute, every change of generations of information technology requires not just training and retraining, but a radical change in 
thinking of professionals and users, equipment, etc. It is noted that the development and use in many areas of human life NBIC-technologies necessitate, firstly, the acceptance of the inevitability of the process of application of advanced technologies, no matter how incredible and fantastic the consequences of their implementation, and secondly - consistent cultural understanding and adequate support of achievements and risks associated with this process.

Keywords: Gartner Hype Cycle methodology; information and communication technologies; patterns of development of information and communication technologies

\section{GARTNER HYPE CYCLE КАК МЕТОДИКА АНАЛИЗА ЗАКОНОМЕРНОСТЕЙ РАЗВИТИЯ ИНФОРМАЦИОННО- КОММУНИКАЦИОННЫХ ТЕХНОЛОГИЙ}

\section{- Трач Юлия Васильевна}

Кандидат педагогических наук, профессор, ORCID: 0000-0003-2963-0500, e-mail:0411@ukr.net, Киевский национальный университет культуры и искусств, Киев, Украина

\section{Аннотация}

Цель статьи - охарактеризовать Gartner Hype Cycle methodology как попытку выявления закономерностей развития современных информационно-коммуникационных технологий. Методология исследования основана на применении общенаучной группы формально-логических методов, таких как анализ, синтез, абстрагирование, а также системного и структурно-функционального подходов. Научная новизна заключается в том, что в работе расширено представление о методиках анализа тенденций и закономерностей развития современных информационно-коммуникационных технологий, обращено внимание на необходимость учета данных имеющихся методик оценки состояния развития ИКТ в гуманитарных исследованиях для получения более обоснованных выводов. В статье акцентировано на необходимости всестороннего и детального анализа с точки зрения гуманитаристики достижений, тенденций, закономерностей и перспектив развития информационно-коммуникационных технологий - одного из ключевых фракторов жизнедеятельности современного общества. Представлена классификация ИКТ, основанная на учете видов и способов получения и обработки инфрормации. Приведен подробный анализ Gartner Hype Cycle methodology, обращено внимание на ее недостатки. Выводы. Отмечено, что поскольку сфрера информационных и коммуникационных технологий подвержена постоянным изменениям и чрезвычайно быстрому, а главное - непредсказуемому развитию чуть ли не ежеминутно, то каждая смена поколений средств информационной технологии требует не просто обучения и повышения квалификации, а радикального изменения мышления специалистов и пользователей, изменения оборудования и тому подобное. Обращено внимание, что разработка и использование в многочисленных сферах жизнедеятельности человека NBIC-технологий вызывает необходимость, во-первых, 
принятия неизбежности процесса применения прогрессивных технологий, какими бы невероятными и фантастическими ни казались последствия их внедрения; во-вторых, последовательного культурологического осмысления и адекватного сопровождения связанных с этим процессом достижений и рисков.

- Ключевые слова: методика Gartner Hype Cycle; информационно-коммуникационные технологии; закономерности развития информационно-коммуникационных технологий 